\title{
Postoperative Computed Tomography Assessment of Pedicle Screw Placement Accuracy
}

\section{Ameliyat Sonrası Cekilen Bilgisayarlı Tomografi Görüntülerinde Pedikül Vidalarının Yerleșim Doğruluğunun Belirlenmesi}

\begin{abstract}
AIM: Pedicle screw instrumentation is widely used in the lumbar spine as a means of stabilization to enhance arthrodesis and has gained acceptance in the thoracic spine in recent years. The purposes of this study were to determine the incidence of screw misplacement, complications, the accuracy and usefulness of CT scan in evaluation of pedicle screw placement.

MATERIAL and METHODS: Postoperative CT was performed in all 53 cases to evaluate implant position within first month after surgery. The CT scans were obtained with 2-mm axial slices of the instrumented levels. These images were then inspected for evidence of pedicle violation.

RESULTS: In assessing 247 pedicle screws inserted in 53 patients, lateral screw misplacement was observed in 59 screws $(67.82 \%)$ and medial pedicle wall violation in 28 screws $(32.18 \%)$. Of the 87 misplaced screws, 41 cases were classified as minor (cortical perforation $\leq 2 \mathrm{~mm}), 41$ cases as moderate $(2.1-4 \mathrm{~mm}$ ), and 5 cases as severe penetration $(>4 \mathrm{~mm}$ ). Nerve root injury with radicular pain and neurological deficits was observed in 8 patients with malpositioned screws (15.09\% of all patients).
\end{abstract}

CONCLUSION: Pedicle screw placement is a technically demanding procedure with a high complication rate. Fortunately, most complications are not severe.

KEYWORDS: Pedicle screw, Misplacement, Fusion, Computed tomography

\section{ÖZ}

AMAÇ: Lomber bölgede stabilizasyonu ve artrodezi sağlamak için pedikül vidaları kullanılmaktadır ve son yıllarda torakal bölgede de pedikül vidası kullanımı artış göstermektedir. Çalışmamızda, vidaların yerleşim kusurları, bunlara bağlı komplikasyonlar ve bilgisayarlı tomografik incelemelerin vida yerleşimini göstermesinin güvenilirliği incelenmiştir.

YÖNTEM ve GEREÇ: Toplam 53 olguda cerrahi işlemden 1 ay sonra bilgisayarlı tomografi çekimleri yapılmış ve vida yerleşimleri değerlendirilmiştir. Bilgisayarlı tomografi çekimleri horizontal planda vidaların olduğu bölgelerden $2 \mathrm{~mm}$ aralıkta geçen kesitler şeklinde alınmıştır. Elde edilen tüm kesitler pedikül ve vida ilişkisi açısından değerlendirilmiştir.

BULGULAR: Toplam 53 hastaya uygulanan 247 pedikül vidası incelenmiştir. Ellidokuz vida lateralde görülmüştür $(\% 67,82)$. Yirmisekiz vidanın medial duvardan kanala doğru gönderildiği izlendi $(\% 32,18)$. Vidaların 87'si yanlış yönlendirilmiş olarak bulundu. Kırk bir vidanın yönlenmesinde minör kortikal kırıklar (kortikal kırık $\leq 2 \mathrm{~mm}$ ), 41 vidada orta düzeyde kortikal kırık (kortikal kırık 2,1- $4 \mathrm{~mm}$ ) ve 5 vidanın ağır kortikal kırık yaptığı izlendi (kortikal kırık $>4 \mathrm{~mm}$ ). Toplam 8 hastada yanlış yönlendirilmiş vidaya bağlı olarak kök hasarı nedeni ile kök ağrısı ve nörolojik defisit geliştiği görüldü (tüm olgularda \%15,09).

SONUÇ: Omurgaya pedikül vidası yerleştirilmesi teknik olarak dikkat ve beceri isteyen bir işlemdir ve bu işleme bağlı olarak yüksek komplikasyon hızı vardır, ancak görülen komplikasyonların çoğunluğu ciddi komplikasyonlar değildir.

ANAHTAR SÖZCÜKLER: Pedikül vidaları, Yerleşim kusurları, Füzyon, Bilgisayarlı tomografi

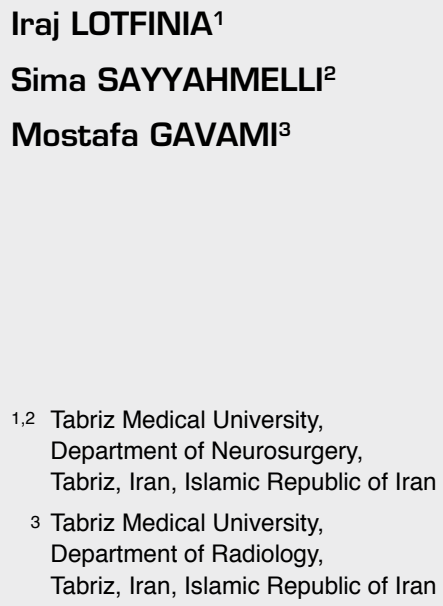




\section{INTRODUCTION}

Indications for pedicle screw instrumentation include stabilization in the setting of trauma, deformity, tumors, infections, degenerative conditions and reconstruction. Since the introduction of pedicle screws, accuracy of placement has been the subject of many studies, in which a wide range of screw malposition rates have been reported (1-25).

Pedicle screw instrumentation is widely used in the lumbar spine as a means of stabilization to enhance arthrodesis and has gained acceptance in the thoracic spine in recent years (5).

The main problem at surgery is that a blind technique is used; the surgeon does not see the pedicle (10). The risk of iatrogenic injury must be minimized as vital anatomic structures surround the pedicle: the dural sac medially, the nerve roots superiorly and inferiorly, and the vascular structures anterolaterally. Further, the accuracy of pedicle screw insertion is crucial for the efficiency and stability of the surgical procedure $(5,10)$. For accuracy, pedicle screw instrumentation may be guided by anatomic landmarks, preoperative imaging, and intraoperative imaging tools such as plain radiography, fluoroscopy, and, more recently, image-guided technology $(3,4,5$, $8,12,18,21,22)$.

The development of instrumentation techniques to stabilize and correct the injured or diseased thoracolumbar and lumbar spine has made enormous progress during recent years. Researchers have reported that transpedicular screw fixation is superior to anterior instrumentation and posterior hook-rod fixation because the pedicle offers a strong point of attachment (4).

Pedicle screw placement does not pose the same high risk of damage to the spinal cord, dural sac, and nerve roots in the lumbar region as it does in thoracic and cervical spine. However, accurate anatomic knowledge is needed to perform a safe surgical intervention in the lumbar region (8).

Frequently during the postoperative period, a surgeon must evaluate new complaints of pain or new neurological deficit. With the use of a pedicle screw system, it becomes imperative that a causal relation between the screws and neurological complication be ruled out (25).

Concerns regarding safety, potential complications if screws are misplaced, and loss of mechanical advantage with pedicle wall disruption, have focused attention on screw placement techniques (21).

The rate of malplaced screws still may be considerable and has been reported to range up to nearly 40\% (13). Many more misplacements occurred but went unobserved (11).

In a review of the literature, noted a $28.1 \%$ to $39.9 \%$ pedicle screw malposition rate in clinical studies and a $5.5 \%$ to $31.3 \%$ malposition rate in cadaver studies. The percentage of malpositioned screws may be higher when normal anatomic landmarks have been obscured, as with revision surgery in the setting of a posterolateral fusion (9).

Although neurological deficits related to screw misplacement are less common, asymptomatic violations of the cortical bone can result in a weakened biomechanical construct. These risks are amplified in the thoracic spine, where the spinal cord is in closer proximity and pedicle size is reduced (24).

Intraoperative fluoroscopy and serial radiography only demonstrate the depth of screw penetration but cannot be used to recognize screw malpositioning (2).

The gold standard for detecting pedicle screw penetration in cadaveric studies has been direct observation at dissection (13).

Although it is generally believed that CT imaging is more accurate than conventional radiography in determining pedicle screw location, particularly in the setting of medial and lateral pedicle perforation, a range of accuracies for both radiographic and CT assessed perforations has been reported (3). However, no clear data currently exist on the sensitivity or the specificity of using CT images in identification of pedicle screw placement (25).

Until the late 1990s postoperative CT assessment was limited to only those patients whose condition deteriorated postoperatively or those participating in experimental or prospective studies, as in many institutions CT is not routinely performed after surgery (6). Despite modern techniques, the incidence of pedicle screw misplacement in the lumbar spine remains significant (12).

Recent challenges in research on pedicle instrumentation have centered on decreasing the risk of malpositioned pedicle screws (19). 
The purposes of this study were to determine the incidence of screw misplacement, complications, the accuracy and usefulness of CT scan in evaluation of pedicle screw placement and to define the relation between the symptoms and the CT scan images. The results were compared with published data on the use of this and other techniques.

\section{MATERIAL and METHODS}

Preoperative anteroposterior and lateral radiographs were taken and inspected to rule out underlying osseous pathology or deformity and Preoperatively, CT and MR imaging were performed in all cases.

All surgeries were performed by the senior author experienced in spinal surgery at a single centre. The patient was placed in the prone position, and a posterior midline incision was made.

All patients received a single dose of cefazolin preoperatively.

A standard posterior approach was used in all cases, paraspinal musculature was dissected from the posterior elements of the spine, and decompressive procedures were performed, including partial or total facetectomies, discectomies, and laminectomy, if necessary.

The screw entry point was identified by using anatomical landmarks locating the intersection of the spine of the transverse process with the corresponding facet and the trajectory of the screw were confirmed by fluoroscopy in the lateral projections. During surgery, fluoroscopy in only lateral plane was used.

The cortex overlying this site was removed with a rongeur and an awl $4 \mathrm{~mm}$ in diameter was used to drill the pedicle screw pilot hole and the pathway was opened with a pedicular probe. The probe then was advanced manually 30 to $35 \mathrm{~mm}$ and its position checked with fluoroscopy. The hole was tapped and then a pedicle tester was used to determine if the pedicle wall had been breached. A pedicle feeler was used to confirm the presence of bone in all four quadrants. If this had occurred, the entry point was changed at the same segment or moved one level up or down until the intact pedicle wall was prepared. For correct placement of a pedicle screw, it is imperative that the screw be directed down the cancellous tunnel of the vertebral pedicle. Finally, the screw was inserted using fingertip pressure only. After each screw had been placed, fluoroscopy was used to confirm the pedicle screw trajectory.
After screws were inserted into the pedicles, were connected with a titanium rod. If a laminectomy or a wide exposure was performed, the screws were also inserted by direct pedicle visualization and palpation.

All of the implants used in this study were made entirely of titanium. No intraoperative neurophysiological monitoring was performed.

After surgery, the patients were examined neurologically by an independent observer to assess neurological deficits preoperatively not present.

Postoperative anteroposterior and lateral plain radiographs were performed within 48 hours after surgery, before patient mobilization. Postoperative CT was performed in all 53 cases to evaluate implant position within first month after surgery. The CT scans were obtained with 2-mm axial slices of the instrumented levels. These images were then inspected for evidence of pedicle violation.

All accuracy evaluations were performed by an independent observer not involved in the surgeries (a radiologist). The observer did not have any knowledge about the operative technique used.

Evaluation of screw placement was performed according to the criteria published by Learch et al (5).

Screw placement was considered correct when the screw was completely surrounded by the pedicle and no portion of the screw perforated outside the cortex. Penetration of the pedicle screw was measured in millimeters using the scale on the CT image. If the penetration of the pedicle screw was 2 $\mathrm{mm}$ or more along the pedicle inferiorly, superiorly, laterally, medially, or anywhere from the corpus, it was assessed as misplaced. Penetration was further subdivided-based on measurement of the distance that the edge of the screw thread extended outside the pedicle cortex-into minor $(\leq 2.0 \mathrm{~mm})$, moderate (2.1-4 mm), and severe $(>4 \mathrm{~mm})$. Depending on the direction of the pedicle violation, the screw misplacement was noted as lateral, medial, inferior, or superior, and right or left. The incidence of intraand postoperative complications not related to screw position as well as hardware failures were also registered, with a minimum follow-up duration of 6 months.

Some patients with unexplained pain or neurological deficit underwent MRI in the immediate 
postoperative period to ascertain screw positions. When needed, some patients underwent reoperations to redirect misplaced pedicle screws.

All patients were followed clinically and radiologically for at least 6 months after the primary procedure.

After discharge from hospital, clinical and radiological assessment was done at one, three and six months. After one year we followed regularly only those patients who still complained of severe back or leg pain.

Screw position was analyzed qualitatively for placement within or outside the pedicle on CT examination. A quantitative analysis was also developed to determine the accuracy of screw entry and trajectory.

The data from screw positions were subdivided according to error measurement (ideal, $0-2 \mathrm{~mm}$, 2.1-4 mm, and greater than $4 \mathrm{~mm}$ (Figure $1 \mathrm{~A}, \mathrm{~B}, \mathrm{C}, \mathrm{D}$ respectively), error direction (medial, lateral, caudal, cephalic), pedicle side (right or left), vertebral level, and finally, spinal region (thoracic, lumbar, or sacral).

The authors performed all the statistical analyses using SPSS for Windows 16.0. Means and standard deviation of every parameter was calculated. For statistical analysis the chi-squared test was used with $\mathrm{p} \leq 0.05$ regarded as significant.

\section{RESULTS}

We reviewed consecutive cases involving 53 patients (23 male and 30 female) who underwent posterior fixation, involving T6 to S1, between March 2004 and September 2009, with a total of 247 inserted screws. The mean age was 39.09 years with a range of 20-68 years. All patients presented with intractable pain, neurological signs, or both.

The indications for surgery were degenerative instability in 4 cases $(7.54 \%)$, spondylolisthesis in 28 cases $(52.84 \%)$, trauma in 18 cases $(33.96 \%)$ and tumor in 3 cases $(5.66 \%)$. The most frequently fused vertebra was L4 (58 cases) followed by L5 ( 24 cases) and $\mathrm{T} 12$ and L2 (each 24 cases).

In assessing 247 pedicle screws inserted in 53 patients, lateral screw misplacement was observed in 59 screws $(67.82 \%)$ and medial pedicle wall violation in 28 screws $(32.18 \%)$. The remaining 160 screws $(64.78 \%)$ were judged as correctly inserted. Of the 87 misplaced screws, 41 cases as misplacements were classified as minor (cortical perforation $\leq 2 \mathrm{~mm}$ ), 41 cases as moderate (2.1-4 mm), and 5 cases as severe penetration $(>4 \mathrm{~mm})$.The penetration of the five severely $(>4 \mathrm{~mm})$ misplaced screws were lateral in all cases (T10, T12, and L5).

In the L5 pedicle, $26(48.14 \%)$ of 54 screws were misplaced; however, sample size calculation estimated that the number of inserted screws in the thoracic spine was insufficient for a statistically significant study at those levels. We did not observe disc penetration, or anterior overpenetration in the reformatted images.

Nerve root injury with radicular pain and neurological deficits was observed in only eight of the patients with malpositioned screws (15.09\% of all patients).

Eight patients complained of radicular pain: 1 had minor lateral perforation (T11), 1 minor medial perforation (L3), 1 moderate lateral perforation (L4), 1 minor lateral perforation (L4), 1 minor medial perforation (L5), 1 sever lateral perforation (L5), 1

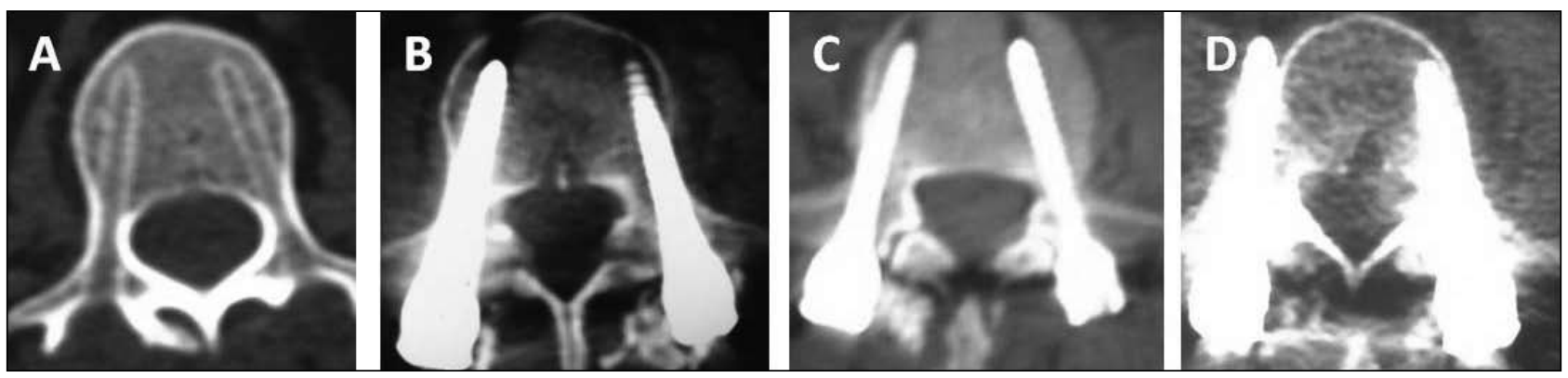

Figure 1: (A) Axial CT image showing the pedicle screw is completely contained within the pedicle, $(\boldsymbol{B}) \leq 2 \mathrm{~mm}$ perforation of the lateral wall of the right pedicle, (C) 2.1-4 mm perforation of the lateral wall of the right pedicle, $(D)>4 \mathrm{~mm}$ perforation of the lateral wall of the right pedicle. 
Table I:

\begin{tabular}{|c|c|c|c|c|c|c|c|c|}
\hline Vertebra & $\begin{array}{c}\text { Number } \\
\text { of } \\
\text { screws }\end{array}$ & $\begin{array}{l}\text { Incorrect } \\
\text { screws }\end{array}$ & $\begin{array}{c}\text { Minor } \\
\text { medial } \\
\text { perforation }\end{array}$ & $\begin{array}{c}\text { Minor } \\
\text { lateral } \\
\text { perforation }\end{array}$ & $\begin{array}{c}\text { moderate } \\
\text { medial } \\
\text { perforation }\end{array}$ & $\begin{array}{c}\text { Moderate } \\
\text { Lateral } \\
\text { perforation }\end{array}$ & $\begin{array}{c}\text { Sever } \\
\text { medial } \\
\text { perforation }\end{array}$ & $\begin{array}{c}\text { Sever } \\
\text { Lateral } \\
\text { perforation }\end{array}$ \\
\hline T6 & 6 & 1 & 1 & & & & & \\
\hline $\mathrm{T} 7$ & 4 & 1 & & 1 & & & & \\
\hline $\mathrm{T} 8$ & 4 & 2 & 1 & & & 1 & & \\
\hline T9 & 6 & 1 & & & 1 & & & \\
\hline $\mathrm{T} 10$ & 8 & 2 & & & & 1 & & 1 \\
\hline T11 & 10 & 5 & 2 & 2 & & 1 & & \\
\hline $\mathrm{T} 12$ & 24 & 10 & 3 & 2 & & 3 & & 2 \\
\hline L1 & 20 & 3 & 1 & 1 & 1 & & & \\
\hline L2 & 24 & 5 & 2 & 1 & 1 & 1 & & \\
\hline L3 & 17 & 4 & 2 & & & 2 & & \\
\hline L4 & 58 & 24 & 5 & 6 & & 13 & & \\
\hline L5 & 54 & 26 & 6 & 4 & 1 & 13 & & 2 \\
\hline S1 & 12 & 3 & 1 & & & 2 & & \\
\hline
\end{tabular}

correct screw position (L5), and moderate lateral perforation (S1) (Table I).

All of severe and moderate misplacements caused no visceral lesion.

Of the remaining patients with malpositioned screws were completely asymptomatic.

Most neurological problems were related to minor (cortical perforation $\leq 2 \mathrm{~mm}$ ) penetration, that with $\mathrm{P}=0.005$ was statistically significant.

Two of the 3 patients with neurological deficit had completely recovered their motor or sensory function after screw repositioning. One patient with neurological deficit, severe pain, and dorsi-flextion weakness underwent early revision surgery that experienced increased pain postoperatively despite absence of signs of root injury and no obvious root compression.

Other patients with radicular pain or paresthesias experienced improvement over 2 weeks to 6 months with conservative treatments and did not require additional surgery.

Other patients with screw malposition did not require revision surgery because they were asymptomatic and showed no radiographic signs of instability.

No patient developed adjacent segmental instability after surgery. No assembly disengagement or broken screws were noted in any patient during follow-up.No infections were observed in the study group. The malpositionings were not related to any specific level.

\section{DISCUSSION}

Although the use of the pedicle screw in the spine has many advantages over previous techniques, the safety issues with these screws continue to be evaluated (19).

Pedicle screws can be used in all age groups of patients, including pediatric and elderly patients, with good results (16).

With this study, we demonstrate that reliance on the CT scan data alone in determining the accuracy of pedicle screw placement can lead to inaccuracies in both clinical and research situations.

In real clinical situations, the diagnosis of pedicle screw misplacement would rarely be made with the CT scan data alone (25).

Accurately placing pedicle screws is important to the biomechanical integrity of spinal implant construct as well as the safety of the patient. Lumbar pedicle screws are one of the most-used forms of spinal fixation in a wide variety of spinal pathologies. Thoracic pedicle screws are used less commonly, although their popularity has increased in recent years, especially in trauma and deformity surgery (5). 
Although instrumentation techniques of the spine, using the pedicle as a source of purchase from posterior into the vertebral body, have become an increasingly popular form of spinal fixation, they are not without complications. Relevant studies present the potential risk of damaging the nerve roots, dural sac, vascular structures, and pleura as a major limitation of pedicle screw instrumentation in lumbar spine $(4,8,22)$.

Upon comparison of pedicle screws, wires, and hooks, the highest incidence of symptomatic impingements occurs with pedicle screws, with nerve root injury or irritation occurring in a reported $3.2 \%$ of cases $(3,4)$.

Laine et al noted a $28.1 \%$ to $39.9 \%$ screw malposition rate in clinical studies and a $5.5 \%$ to 31.3\% malposition rate in cadaver studies (9).

Pedicle screw insertion resulting in neurological deficit is rare but may be due to faulty placement of the screw with perforation of the cortex and impingement on adjacent neural structures $(2,3,4)$. Despiteimprovementsin the design of theinstruments and attention to insertion techniques, cortical perforation does occur $(3,4)$. Many transgressions are asymptomatic and the true incidence is not known (3).

In our study, faulty placement of the screw was seen in $35.22 \%$ cases. The risk of neurologic injury following cortical perforation by a pedicle screw is due to the pedicle's proximity to the neural elements. Medially, the pedicle cortex is separated from the dural sac by a thin layer of epidural fat, which is typically $2 \mathrm{~mm}$ in thickness. Nerve root irritation may be more common with medially placed screws $(3,4)$. Castro et al performed a study of 30 patients with 131 screws placed under fluoroscopic control. Computed tomography (CT) images showed cortical penetration in $40 \%$ and medial wall penetration in $29 \%$ (4).

Farber et al inserted 74 pedicle screws in 16 patients and evaluated the sensitivity of radiographic assessment of cortical perforation, using CT as the gold standard. In their study, 21/74 (28\%) of pedicle screws violated the medial pedicle cortex on CT imaging, despite the performance of a midline laminectomy to palpate the pedicle during screw insertion (3).
In our study, pedicle screws violated the medial pedicle cortex on CT imaging were seen in $32.18 \%$ cases.

The discrepancy between radiographs and CT was most striking with medial misplaced screw, where CT depicted 10 times as many definite or questionable violations of the pedicle cortex than did conventional radiographs (3).

There is a little space between the dural sac and pedicles at all levels and increases from $1.29 \mathrm{~mm}$ at the L1 level to $1.56 \mathrm{~mm}$ at the L5 level (4).

Ideally, the pedicle screw is completely contained within the pedicle, and the spinal canal is not violated (3). (Figure 1A)

Lumbar pedicles have a unique structure, and their relations with neural structures have important implications for surgical interventions. Although successful and encouraging results have been presented in some studies, the complications which may emerge during surgery can be very serious. Reported studies are few in this area, and the true incidence of complications is not certain; it may be much higher than current estimates, owing to possible under-reporting (8).

Pedicle screws that violate the pedicle cortex increase the risk of neurologic injury; however, minor violations of the cortex are not uncommon and may be asymptomatic. In these cases, the screw position may be acceptable. Ultimately, patient symptoms are probably the most important factor in determining acceptable positioning of the screw (4).

Fluoroscopically assisted pedicle screw placement is an accepted method of providing safe pedicle screw placement with efficacy established in a cadaveric study (21).

Pedicle penetration occurred more often in medial and lateral walls and less in superior and inferior walls. This was because of the anatomy of the pedicle (8). In our study, the superior and inferior walls were not penetrated.

Pedicle penetration also occurred more often in lateral than medial walls, as in our study (18).

Moreover such pedicle screws malpositioning may result in loss of fixation $(6,18)$, especially if it occurs at the lower end of a construct. Therefore, proper placement of pedicle screws is important not only for the prevention of neurological injury but 
also for the maintenance of long-term spinal stability. Clinical studies on conventional pedicle screws placement have reported a malpositioning rate of up to $42 \%$ in the thoracic and lumbar spine. Many studies have demonstrated that $\mathrm{CT}$ is more accurate than conventional radiography in determining pedicle screws location. As one can deduce from other studies, the minimal cortical effraction latter group should not be regarded as misplaced screws, because they are not responsible for neurological symptoms or failure of fixation, and most authors have not included such cases in their misplacement reporting. In the current study, the incidence of neurological injury, defined as the presence of sensory and/or motor deficits, was $15.09 \%$ (6).

Clinical and experimental studies have shown that the use of image-guided navigation techniques significantly reduces the rate of pedicle perforation and screw malpositioning, compared with the conventional method (6).

Other authors' analyses of in vivo CT findings reported reductions in rates of misplacement from 42 to $8 \%, 14.3 \%$ to $4.3 \%$, and 15 to $5 \%$, using conventional and computer-assisted methods, respectively.

In addition, the navigation determines the starting point and the trajectory, but no guidance is used when the actual pedicle screw is inserted (6).

The rate of repeated surgery and complications related to screw placement also seems to be lower, in our study.

Previous studies rarely showed the effect of improper screw placement on late instability (6).

One patient in our series underwent early revision surgery; in 2 who had misplaced screws, the screws were repositioned because of neurological disfunction.

Yoo et al reported there was no identifiable correlation between years in clinical practice and accuracy, suggesting that greater experience does not lead to improved accuracy (3).

Anatomic variation and disease-induced alterations resulting in scoliosis or rotational malalignment make the radiographic interpretation of pedicle screw placement much more difficult. Accurate guidelines for interpreting pedicle screw placement in such patients need to be developed (3).
Recent improvement in CT technology, in particular multislice $\mathrm{CT}$, has allowed for improved imaging of hardware due to less metallic artifact. Additionally, this technology allows for improved reformatted images in sagittal and coronal planes. This should further improve diagnostic accuracy to $\mathrm{CT}$ in the future (3).

Most of the important conventional radiographic information can be ascertained from the PA film, and this appears to be the most valuable radiograph in localizing pedicle misplacement. The lateral film may aid in confirming position, especially if the pedicle shadow is not well demonstrated. When bilateral screws are present at a given level, interpretation of the lateral radiograph will be more challenging (3)

Lumbar fusions for degenerative segmental instability undergo a concomitant decompressive laminectomy at the instrumented levels only if stenosis is present. As such, lumbar fusions do not always require a therapeutic lumbar laminectomy at the level of the fusion (3). In our study. laminectomy at the level of the fusion was performed in $71.69 \%$ of the cases.

However, accurate placement of pedicle screws may be guided by performing a laminectomy, thereby permitting visualization and palpation of the pedicle to guide screw placement (12). In this study, correlation between lateral placement of pedicle screws and laminectomy was statically significant $(\mathrm{P}=0.001)$.

It is possible that the surgeon choose a more lateral trajectory away from the visualized or palpated medial wall of the pedicle (12).

Deviation in screw trajectory, screw-pedicle mismatch and short depth penetration caused inadequate correction of the deformity and led to further stability failure as it might have reduced the pull-out strength (1).

George et al. showed in a human cadaver study that the fracture of a pedicle during screw insertion reduced the pull-out strength of the screw by $11 \%$ compared with an intact pedicle (1).

Neurological complication due to a misplaced pedicle screw can result in profound and permanent physical impairment to the patients undergoing spinal fusion and instrumentation $(18,23,25)$. 
Postoperative radicular leg pain may be due to intraoperativemanipulation of thenerve roots without any ongoing neurocompression. Reexploration of these spines would not be fruitful, even detrimental. Conversely, a misplaced pedicle screw may present as radicular leg pain without any motor deficit. If this condition is left alone, then profound motor deficit may ensue. Making an accurate diagnosis of proper pedicle screw placement is imperative, to minimize false reexploration and maximize proper and prompt treatment of the misplaced screw (25).

\section{CONCLUSION}

Evaluation of pedicle screw placement is difficult even in experienced hands. Pedicle screw placement is a technically demanding procedure with a high complication rate. Fortunately, most complications are not severe. When the patient shows a neurological deficit after surgery, CT scanning is indicated to document the location of the pedicle screws.

\section{REFERENCES}

1. Acikbas SC, Arslan FY, Tuncer MR: The effect of transpedicular screw misplacement on late spinal stability. Acta Neurochir 145: 949-955, 2003

2. Açikbas SC, Tuncer Mr: New method for intraoperative determination of proper screw insertion or screw malposition. J Neurosurg(Spine 1) 93: 40-44, 2000

3. Ahlgren BA, Learch TJ, Massie JB, Pathria MN, Garfin SR: Assessment of pedicle screw placement utilizing conventional radiography and computed tomography: A proposed systematic approach to improve accuracy of interpretation. Spine 29(7): 767-773, 2004

4. Akyildiz F, Söyüncü Y, Yildirim FB, Sekban H, Ozdemir H, Sindel M: Anatomic evaluation and relationship between the lumbar pedicle and adjacent neural structures an anatomic study. Spinal Disord Tech 18: 243-246, 2005

5. Albert TJ, Grauer JN, Vaccaro AR, Brusovanik G, Girardi FP, Silveri CP, Cammisa FP, Kwon BK, Beiner JM, Hilibrand AS, Scuderi GJ: Evaluation of a novel pedicle probe for the placement of thoracic and lumbosacral Pe dicle screws. Spinal Disord Tech 17: 492-497, 2004

6. Amato V, Giannachi L, Irace C, Corona C: Accuracy of pedicle screw placement in the lumbosacral spine using conventional technique: Computed tomography postoperative assessment in 102 consecutive patients. J Neurosurg Spine 12: 306-313, 2010

7. Amiot LP, Lang K, Putzier M, Zippel H, Labelle H:Comparative results between conventional and computer-assisted pedicle screw installation in the thoracic, lumbar, and sacral spine. Spine 25: 606-614, 2000

8. Attar A, Ugur HC, UzA, Tekdemir I, Egemen N, Genc Y: Lumbar pedicle: Surgical anatomic evaluation and relationships. Eur Spine J 10: 10-15, 2001

9. Austin MS, Vaccaro AR, Brislin B, Nachwalter R, Hilibrand AS, Albert TJ: Image-guided spine surgery; a cadaver study comparing conventional open laminoforaminotomy and two image-guided techniques for pedicle screw placement in posterolateral fusion and nonfusion models. Spine 27: 2503-2508, 2002

10. Castro WH, Halm H, Jerosch J, Malms J, Steinbeck J, Blasius S: Accuracy of pedicle screw placement in lumbar vertebrae. Spine 21: 1320-1324, 1996

11. Glossop ND, Hu RW, Randle JA: Computer-aided pedicle screw placement using frameless stereotaxis. Spine 21: 2026-2034, 1996

12. Gonzalez-Cruz J, Karim A, Mukherjee D, Ogden A, Smith D, Nanda A: Accuracy of pedicle screw placement for lumbar fusion using anatomic landmarks versus open laminectomy: A comparison of two surgical techniques in cadaveric specimens: Operative Neurosurgery 1: 13-19, 2006

13. Grauer JN, Vaccaro AR, Brusovanik G, Girardi FP, Silveri CP, Cammisa FP, Kwon BK, Beiner JM, Albert TJ, Hilibrand AS, Scuderi GJ: Evaluation of a novel pedicle probe for the placement of thoracic and lumbosacral pedicle screws.J Spinal Disord Tech 17: 492-497, 2004

14. Hailong Y, Wei L, Hongxun S, Zhensheng M: Computer analysis of the safety of using three different pedicular screw insertion points in the lumbar spine in the Chinese population. Eur Spine J 16: 619-623, 2007

15. Jutte PC, Castelein RM: Complications of pedicle screws in lumbar and lumbosacral fusions in 105 consecutive primary operations. Eur Spine J 11: 594-598, 2002

16. Kosay C, Akcali O, Berk RH, Erbil G, Alici E: A new method for detecting pedicular wall perforation during pedicle screw insertion. Spine 26 : 1477-1481, 2001

17. Lee TC, Yang LC, Liliang PC, Su TM, Rau CS, Chen HJ: Single versus separate registration for computer-assisted lumbar pedicle screw placement. Spine 29: 1585-1589, 2004

18. Li B, Jiang B, Fu Z, Zhang D, Wang T: Accurate determination of isthmus of lumbar pedicle: A morphometric study using reformatted computed tomographic images. Spine 29: 2438-2444, 2004

19. Meter JJ, Polly DW Jr, Miller DW, Popovic NA, Ondra SL: A method for radiographic evaluation of pedicle screw violation of the vertebral endplate: Technique. Spine 21: 1587-1592, 1996

20. Pihlajämaki H, Myllynen P, Böstman O: Complications of transpedicular lumbosacral fixation for non-traumatic disorders. J Bone Joint Surg 79-B: 183-189, 1997

21. Robertson PA, Stewart NR: The radiologic anatomy of the lumbar and lumbosacral pedicles. Spine 25: 709-715, 2000

22. Roy-Camille R, Saillant G, Mazel C: Internal fixation of the lumbar spine with pedicle screw plating. Clinical Onhopaedics and Related Research 203: 7-17, 1986

23. Schwarzenbach O, Berlemann U, Jost B, Visarius H, Arm E, Langlotz F, Nolte LP, Ozdoba C: Accuracy of computer-assisted pedicle screw placement: An in vivo computed tomography analysis. Spine 22: 452-458, 1997

24. Wang MY, Kim KA, Liu CY, Kim P, Apuzzo ML: Reliability of three-dimensional fluoroscopy for detecting pedicle screw violations in the thoracic and lumbar spine. Neurosurgery 54 : 1138-1143, 2004

25. Yoo JU, Ghanayem A, Petersilge C, Lewin J: Accuracy of using computed tomography to identify pedicle screw placement in cadaveric human lumbar spine. Spine 22: 2668-2671, 1997 